\title{
Sustainable Rural Development and Livelihood Sources of the Rural Households in Mountainous Pakistan
}

\author{
Muhammad Israr ${ }^{1, *}$, Asif Yaseen ${ }^{2}$, Shakeel Ahmad ${ }^{3}$ \\ ${ }^{1}$ Department of Rural Development, Faculty of Rural Social Sciences AMKC, Mardan, \\ The University of Agriculture Peshawar, Pakistan \\ ${ }^{2}$ ARC Industrial Transformation Training Center (ITTC), The University of Queensland, Brisbane, St. Lucia, Australia \\ ${ }^{3}$ Department of Environmental Sciences, COMSATS Institute of Information Technology, Abbottabad, Pakistan \\ *Corresponding author: misrar@aup.edu.pk
}

\begin{abstract}
Livelihoods of the rural households in the developing regions are still dependent on farm and off-farm economic activities and this approach emerged from a range of efforts to understand that how the people survive in a particular area. Empirical research conducted on this subject give diverse results in this respect. The main purpose of the present study was to analyze the livelihood sources and the level of participation of the rural household in various economic activities and their contribution towards the households' income in northern parts of Pakistan. Primary data was collected through random sampling methods from 323 household's head. Findings of the study reveal that the rural people are engaged in multiple economic activities including both farm (crop, livestock, forestry, rent land, agriculture wages, hiring out farm machinery, fodder and sale of fruits and vegetables) and off-farm (small-scale businesses, services, foreign and domestic remittances, and off farm wages) for their survival. The lion share of contribution towards household's income from farm livelihood sources was the income from crops and livestock. In non-farm economic activities public/private sector employment was the major source of non-farm source of livelihood for the rural households in the research area. The average annual income per household from crops was Rs. 65,340, followed by income from forests and livestock respectively. On average, households were earning Rs. 4,33,390 per annum from these sources. The study concludes that the farm sources of income contribute more to the livelihood of the rural people than the non-farm sources of income and hence having play crucial role in the reduction of poverty. The study recommends preservation and a sustainable use of the farm resources so that to overcome the problems faced by the future generation and the creation of more nonfarm activities for sustainable livelihood.
\end{abstract}

\section{Keywords: livelihoods, farm and non-farm income, sources of income and rural areas}

Cite This Article: Muhammad Israr, Asif Yaseen, and Shakeel Ahmad, "Sustainable Rural Development and Livelihood Sources of the Rural Households in Mountainous Pakistan." American Journal of Rural Development, vol. 5, no. 4 (2017): 97-102. doi: 10.12691/ajrd-5-4-2.

\section{Introduction}

Development is a multidimensional phenomenon and the latest literature agrees that it is about enlarging human choices $[20,22]$ while before this it was consider as to fight against poverty and to have a long-term economic and social development [31]. Development may occur due to some determined action conceded out by individual or by some culture/society to achieve perfection [20]. This implies that development and livelihood are interlinked with each other because the poor and rich both peruse livelihood for living [25]. Livelihood in the multidimensional point of view recognizes the suppleness and constraints with which people build their composite lives and adapt their livelihoods in self-motivated behavior and the diversification of assets, activities, and social support capabilities can boost livelihoods, and enlarging capabilities and opportunities [12,14,29]. Livelihoods approaches emerged from a wide assortment of hard work to comprehend how people survive in particular places and thus it address social goals as well as material needs of the people and societies [12]. Sustainable livelihood and poverty are interlinked because poverty destroyed human basic rights for existing with minimum opportunities particularly political, social stability and economic processes and environment $[10,21]$. The wider concerns regarding multifaceted livelihoods, environmental dynamics and poverty alert development and linked inputs like capitals or assets and outputs i.e. livelihood strategies, associated in turn to outcomes, which combined proverbial region of poverty lines and employment levels with well-being and sustainability [31].

Thus to enrich livelihood perspectives further, there is a need to be more informed by an explicit theoretical concern with the way class, gender and capitalist relations operate [26], asking up-front who gains and losses and why, embedded in an analysis informed by theories of power and political economy and so an understanding of 
processes of marginalization, dispossession, accumulation and differentiation.

Livelihood is utilized as opposed to work or even wellspring of wage. Most rural people in the developing world work in agriculture or get off-farm job opportunities only seasonally and often part time. Individuals and households create a living from various sources: production (farming, local craftwork, small-scale industries), own labor, trading, transfers (grants and remittances); this last form of entitlement often forms the backbone of rural people's livelihood [6,27].

In the developing world, rural areas are the economic backbone; they contribute to overall economic growth by supplying surplus labor, food and raw materials to other growing sectors of the economy and hence contributed to the development of developing the world. Despite these significant contributions, however, rural areas are the most marginalized. They are characterized by food insecurity, unemployment, poverty, income inequality and lack of important socio-economic services. Reference [9] pointed that the rural areas of the developing world are characterized by the presence of diverse economic activities. Some are farm related and others not. Research has shown that non-farm activities are growing in importance in the developing world for the lives of the rural poor $[9,23,28]$. In developing countries about 1.2 billion people rely on agroforestry farming systems that help to sustain agricultural productivity and generate income [35].

Moreover, off-farm activities also account for a significant proportion of rural households' income. According to reference [18], despite a wide variation, the average share of off-farm income among rural households was $45 \%$ in 25 Sub-Saharan African countries. Rural off-agricultural employment is becoming increasingly important in sub-Saharan Africa [32]. Reference [19] argues that natural resource-based activities may become more or less part-time in character with the current diversification in rural areas.

Living standard of the rural poor would only be uplifted when they receive income from the multiple economic activities at the household level $[1,3,4,8]$. To build a base for social change at the individual level generation of more income activities and opportunities is an essential precondition for the elimination of poverty and the upholding of human rights [24]. When different dimensions of the livelihood issue are considered, the incidence of income is the most important. Income generating activities change the livelihood of the poor in terms of living condition, housing, nutrition, savings, dress, medical treatment, health, sanitation, liberalization and education $[5,13]$.

According to the findings of reference [2,11,16,18,34] that the rural people in Asia and Africa do not normally specialize in livestock, crop or fish production to the total exclusion of other income generating activities. The majority of rural producers have historically diversified their productive activities to encompass a range of other productive areas. Motivations for such diversification are multifarious, linked with a wide range of possible activities, and associated with both positive and negative outcomes.
This study on the livelihood sources in the northern region will contribute to the institutional abilities and also the local people's to escape from poverty because access/income to productive assets leads to a sustainable development and guide the policy makers which sources of the livelihoods needs interventions for future sustainability. It is being realized for some time that rural people no longer remain confined to crop production, fishing, forest management or livestock-rearing but combine a range of occupations to construct a diverse portfolio of activities. To address the issues of food insecurity, unemployment, poverty, income inequality and lack of important socio-economic services in the rural areas the study in hand is designed with the objectives; i) to investigate the livelihood sources and level of participation of the rural household in various livelihood activities, ii) to analyze the livelihood of rural households and their contribution to the household income. The study was hypothesize that the rural population are mainly increased in non-farm business activities due to subsistence farming, and also the non-farmer sector of likelihood contribute more than the farms one.

\section{Material and Methods}

District Shangla was selected purposively as the universe of the present study which is comprised of two Tehsils namely; Alpuri and Puran comprising of twenty-four union councils as shown in the Figure 1. The purposive selection was made due to the reasons that the district is purely rural and the majority of the households are involved in multiple livelihood activities. Four union councils were randomly selected for collecting the required data. There are 111 villages in the sample union councils with 9,999 households. The sample size was determined by the reference [15] formula for sample size calculation and the resulted sample size were 323 . Primary data were collected through a pre-tested questionnaire from the rural household head through face to face interview method. For analyzing the data different statistical techniques were used.

\section{Results and Discussions}

\subsection{Households' Income from Different Sources}

It has already been mentioned that the livelihood sources are classified as farm and non-farm of the rural households. Data presented in Table 1 show the contribution of these sources to total household income before the diversification of income. Average annual income of household from all sources in the area was found to Rs. 2, 52, 578, before the diversification of income. The farm to non-farm ratio of income in the area was 0.68 . This implies that most of the household in the rural areas derived livelihood from non-farm income sources. These are discussed in detailed as follow. 


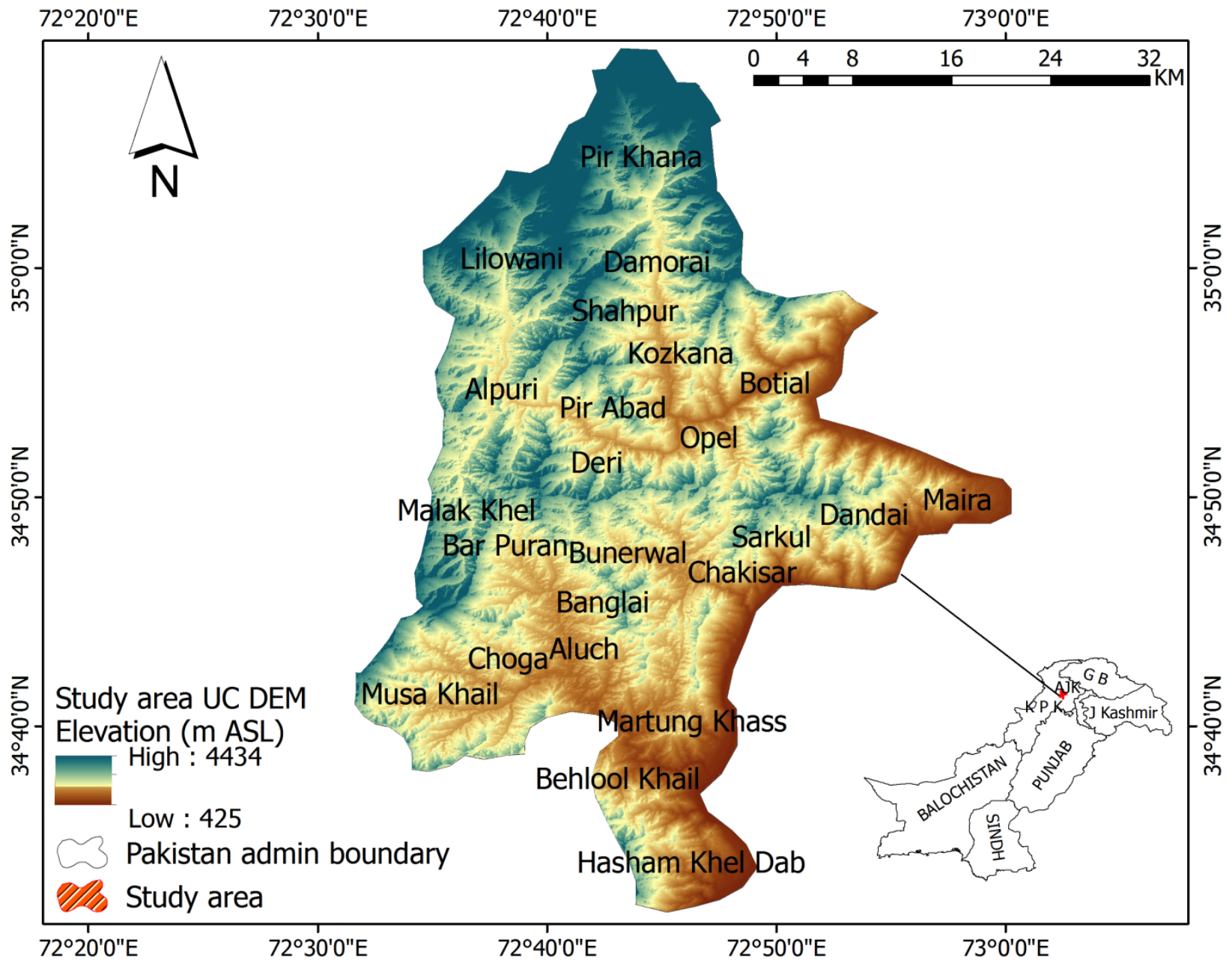

Figure 1. Map of Pakistan, and universe of the study (Source: Own collaboration)

Table 1. Livelihood sources contribution to total income

\begin{tabular}{|c|c|c|c|c|c|}
\hline Source of livelihood & $\begin{array}{c}\text { Average HH } \\
\text { income based on } \\
\text { total HH }(n=323) \\
\end{array}$ & $\begin{array}{l}\text { Percent contribution of } \\
\text { the source of income to } \\
\text { total income }\end{array}$ & $\begin{array}{c}\text { Number of } \\
\text { Households } \\
\text { reporting income }\end{array}$ & $\begin{array}{c}\text { Percent of HH } \\
\text { reporting } \\
\text { income }\end{array}$ & $\begin{array}{c}\text { Average income of } \\
\text { the reporting } \\
\text { households }\end{array}$ \\
\hline Food crops & 50104 & 19.84 & 262 & 81.11 & 61770 \\
\hline Fodder & 1613 & 0.40 & 64 & 19.81 & 9266 \\
\hline Vegetable & 320 & 0.13 & 11 & 3.41 & 23091 \\
\hline Fruits & 2441 & 0.97 & 125 & 38.70 & 14111 \\
\hline (All crops) & 53878 & 23.34 & - & - & - \\
\hline Livestock & 12716 & 5.03 & 137 & 42.41 & 29980 \\
\hline Agric. Wages & 3610 & 1.43 & 66 & 20.12 & 17938 \\
\hline [Agriculture] & 74531 & 29.50 & - & - & - \\
\hline Forest & 20293 & 8.03 & 201 & 62.23 & 32609 \\
\hline$\{$ Agriculture and forestry $\}$ & 94823 & 37.54 & - & - & 32609 \\
\hline Land rented out & 6217 & 2.46 & 63 & 19.50 & 31873 \\
\hline Farm machinery & 1594 & 0.63 & 5 & 1.55 & 103000 \\
\hline Farm related & 102634 & 40.63 & - & - & - \\
\hline Small scale business & 29467 & 11.67 & 64 & 19.81 & 148719 \\
\hline Wages & 6022 & 2.38 & 73 & 22.60 & 26562 \\
\hline Home remittance & 9793 & 3.88 & 53 & 16.41 & 59679 \\
\hline Foreign remittance & 279 & 0.11 & 1 & 0.31 & 90000 \\
\hline (Remittances) & 10071 & 3.99 & - & - & - \\
\hline Public and private services & 61817 & 24.47 & 111 & 34.37 & 179883 \\
\hline Pension & 3065 & 1.21 & 9 & 2.79 & 110000 \\
\hline Other sources & 39537 & 15.65 & 188 & 58.20 & 67928 \\
\hline Non-farm & 149980 & 59.37 & - & - & - \\
\hline All source & 252578 & 100.00 & 323 & 100.00 & 252578 \\
\hline Farm: Non-farm Ratio & 0.68432 & - & - & - & - \\
\hline
\end{tabular}




\subsection{Farm Livelihood Sources Contribution to Total Rural Household Income}

Average annual income per household from farm related activities was Rs. 102634. In percentage terms it was $40.68 \%$. These farm livelihood sources include income from crop, sale fruits and vegetables, livestock, forests, farm machinery and rented out land.

\subsection{Cereal Crops Income}

Cereal crops of the household in the area were maize, wheat and rice. Majority of the respondents $(81.11 \%)$ reported income from this source. However in terms of quantity its contribution was less than the non-farm sources. Average annual income from crops in the project area was Rs. 50104. While the average income of crops reported by household who had grown cereal crops was Rs. 61770 per annum.

\subsection{Fodder Income}

The area under reference is mostly hilly in nature. Majority of the people keep livestock for their own household consumption irrespective of land ownership. Those having agriculture/forest land grow fodder for their own requirement. After fulfilling their fodder need for livestock they sell out the remaining to the fellow farmers in the local area. The data show that in the study area $19.81 \%$ household reported this practice of fodder cultivation. Its contribution to the total household income was $0.73 \%$. The fodder in the area is barley, wheat straw, posture grasses and maize crop residue. The average annual income from fodder in the project area was Rs. 1853. Average income from fodder of those household who reported this income was Rs. 9266 per household.

\subsection{Income from Sale of Vegetable}

The area is most suitable for the cultivation of off-season vegetable. One would expect the growing of off-season vegetables. But our findings do not support this statement. The reason could be lack of off-season cultivation techniques and awareness of benefits of cultivation of these vegetables. Moreover lack of finance could be another obstacle for this response. The results show that only 3.41\% of the household reported income from vegetable. It is important to mention here that only seasonal vegetables were grown by the sample households. Average annual income of households from vegetable was Rs. 786. While average income from the vegetable based on the number of household reported income from was Rs. 23091 per annum. The overall contribution of vegetable to the total income was 0.31 percent.

\subsection{Income from the Sale of Fruits}

Though the area is famous for fruit growing but due to lack of marketing facilities and technical know-how the people of the area is not taking interest in this business. However $38.70 \%$ of the farmers reported having inherited orchards of apple, walnut, plum, pear, persimmon, apricot and persimmon. The contribution of income from the sale of fruit orchard to household income was $2.16 \%$. The average income from this source was calculated as Rs. 5461 per annum while taking as a whole. This figure was Rs: 14111 for the reported household. From the table it is evident that the average income from all crop related sources was Rs. 58204, while the percent contribution of all crop income to the livelihood of the household was 23.04.

\subsection{Livestock Income Contribution to Total Household Income}

Livestock is also one of the important sources of income for supporting the livelihood of the rural household. It supports the livelihood of the rural household through one way or the others. In the area buffalos, cattle, sheep and goat are reared for the livelihood activities. The data Table 2 show that $42.21 \%$ of the respondents reported having income from livestock. The average income of household was Rs. 12716 per year while the reported household income from livestock was Rs. 29,980 per year. Livestock contribution to total income was $5.03 \%$ percent in the area. This was confirmed by the findings of [17] that in Africa rearing of livestock is considered a sign of wealth and household who reared livestock take part at decision at community level and contributed significantly to household income among the farm sources of income.

\subsection{Farm Daily Wages Income}

It is common practice in rural areas that people work with each other on reciprocal basis in peak seasons of farm operation. The culture of working as daily wage laborer is rear. But still some households spare some members of their family for daily wages to supplement the household income. Some of the households hire out the services of their animals for transporting different goods from one place to other. Income from these services is also included to the daily wage income of the households. The data show that $20.12 \%$ of the sample household reporting income from daily wages activities in agriculture. Average household income from daily wages activities in the area was Rs. 3,610; while for the household reported income from this source was Rs. 17938 per annum. The percentage contribution of the daily wages income to total household income was $1.43 \%$ per year.

\subsection{Forest Income}

Forest income is also one of the important rural livelihood supporting income sources in the area. Reference [30] pointed that forest products are especially important for the poorest household to escape from poverty. Being a hilly area income from the sale of timber is one of the important sources of livelihood in the area. The results show that majority of the households $(62.23 \%)$ reported income from the sale of forest trees for fuel/construction purposes. This source was contributing $8.03 \%$ to the households' income. On the average income from forest was Rs. 20293 per annum. If we take only those households who have reported from this source then the average income becomes Rs. 32609 per year. This is related to the findings of [7] that among the farm sources of income forest are the second important contributor to rural household income in Ethiopia. 


\subsection{Income from Rented out Land}

During the field survey some of the landlords who had comparatively more land or due to shortage of family labor had rented out their land on lease to other household. This was reported by $19.50 \%$ of the households. The contribution of the rented land income to the total household income in the area was $2.46 \%$ per year. On the average annual income from rented out land was found Rs. 6217 per household. This figure of income was Rs. 31873 for those who actually reported income from this source. Reference [2] stated that about $80 \%$ of the rental income in rural areas of Pakistan comes from land, whether rented on kinds or in cash.

\subsection{Income from Farm Machinery}

The data in Table 1 show the income of the sample household from farm machinery. The results show that only $1.55 \%$ possessed tractor and its related farm implements. Farm machinery was owned by those who had some of the family members in the Middle Eastern countries and sent foreign remittances in sufficient amount to their homes. They hired out services of this machinery in the village and outside the village and earn income. The overall contribution of farm machinery to the total household income was $0.63 \%$. Taken project area as a whole the average income from this source of livelihood was Rs. 1594 per year. While those was having farm machinery were earning Rs. 1, 03,000 per year.

\subsection{Income from Non-farm Livelihood Sources}

These sources of livelihood were more popular among the sample household. The contribution of non-farm sources to the income of the sample households was more than the income from farm sources. The contribution of the non-farm related activates to total household income was 59.37 percent. The data in the Table 1 also show that on the average the income from these sources Rs. 149980 per year of the sample household. The non-farm related activities income of the household was further subdivided in to small scale business, wages income, remittances both home and foreign, public and private services, pension and other sources of income.

\subsection{Small Scale Business Income}

The overall contribution of small scale business total income was $11.67 \%$. This economic activity was run by 19.81 percent of the households in the study area. Project area taken as a whole the average income from this source was Rs. 29,467 per year. By taking only those household who reported running small scale businesses were earning Rs. $1,48,719$ per year.

\subsection{Daily Wages Income (Non-farm Source Only)}

Income from daily wage in the non-farm sector was its own importance for the rural households. In the off season people resort to this source for supporting their income from this source. In this regard $22.60 \%$ of the households reported income from non-farm daily wages. The contribution of non-farm income to the total income was $2.38 \%$. Average household income from this source of livelihood was Rs. 6,022 per year, while the average income of the reported household from this source of livelihood was Rs. 26,562 per household per year.

\subsection{Remittances Income}

Like other non-farm sources of livelihood remittances were equally popular among the sample households. In rural areas the people live in joint family systems where they can spare extra family labor for sending in search of employment to other parts of the country or abroad from where they send money to back home. The contribution of the remittances to the total household income was 3.99 percent. The average income of the household from both foreign and domestic remittances was Rs. 10071 per year before the diversification of income. Among the remittance the contribution of the domestic remittances was more than the foreign remittances. This was because of the fact that most of the households were poor in the area and cannot afford expenses of going abroad. The home remittance per household in the area as whole was Rs. 9793 per year. While the income for those household reported income from domestic remittances was Rs. 59679 per household per year.

\subsection{Public/Private Services Income}

This source of livelihood was the most popular source of livelihood among the sample households. The data in the Table 1 also show that the contribution of income from services sector to the total household income was $34.37 \%$ in the area. On the average the income from services of the households was Rs. 61,817 per year. Household reporting income from services was having an average income of Rs. 1, 79,883 per year.

\subsection{Pension Income}

Some of the households' members were retired from different public sector jobs and they were getting pension from their respective departments. Such types of households were 2.79 percent in the sample area. The contribution of income from pension to the total household income was only $1.21 \%$. The average income from this source was Rs. 3065 per household per year. Out of the total only 9 household reported income from this source. The average of these 9 households comes to Rs. 1, 10,000 per year.

\subsection{Other Sources Contribution to Total Household Income}

The others sources of income includes income from affiliation with political party, no regular income, income from rent, etc. supporting the livelihood of the household in the area. The data shows that out of total 323 sample household $188(58.20 \%)$ reported for having income from other sources. The contribution of other sources of income to the total household income was $15.65 \%$. The average 
household income based on total household from other sources of income was Rs. 39537 per year per household. Also the average income of the household reporting the income from the other sources was Rs. 67928 per year per household.

\subsection{Household Reporting Income for Different Livelihood Sources}

The data in Table 2 present the information about the household reporting income from different farm and nonfarm sources of livelihood in the area. The results show that $81.1 \%$ household having crop income. The crop income was reported by more households in Shahpur compared with the rest of sample union councils. Livestock was reported by $42.1 \%$ of the sample household as a source of livelihood and the percentage of livestock income among the union councils was more in Lilownai and less in Shahpur. Forest as an income source was reported by $60.4 \%$ of the household and the percentage distribution among the union councils was almost the same. In term of percentage, the $25.1 \%$ of the household answered for having rental income from the land. The higher percentage was noted in Shahpur and lower in Kuzkana union councils. Agriculture wages income was mentioned by $20.7 \%$ household, in which the lower percentage was noted in union council Pirkhana. Income from farm machinery was reported by $20.7 \%$ of the sample household, in which the higher percentage was in Kuzkana and lower in Shahpur. Income from the sale of Fruit was reported by $39.3 \%$ of the respondents. Only $5 \%$ of the respondents reported income from vegetables. Fodder income was also mentioned by $21.4 \%$ of the respondents.

As for as the non-farm income is concerned it was reported by $39.3 \%$ of the respondents they are getting income from small scale businesses. In union councils, the highest percent of small-scale business income was noted in Kuzkana followed by Shahpur. Income for public and private services was also mentioned by $47.7 \%$ of the household and within the sample union councils, the highest involvement in the services sector was reported in Lilownai followed by Kuzkana and lower in Pirkhana. Income from foreign remittances was also reported 15.5\% of the sample respondents. Home remittances income was also reported by $41.8 \%$ of the household and in union councils, the higher percentage was recorded in Pirkhana and Kuzkana and lower in Lilownai. Wages income was also reported by $45.5 \%$ of the sample household. Income from pension was also reported by $2.8 \%$ of the household.

\subsection{Households Income from Livelihood Sources}

The livelihood sources were broadly categorized into the farm and non-farm sources. The income from these sources accrued by the sample respondents is presented in farm and non-farm livelihood sources.

\subsection{Income from Farm Livelihood Sources}

Farm sources of livelihood are generally dominate in rural areas. The findings show that on the average the sample households were earning Rs. 433,390 annually from these sources. Slight variations were found while comparing the income of sample union councils. Lilownai union council had the highest average annual income while union council Shahpur had the lowest annual income. The reason could be the different topography of these union councils. Some parts of these union councils had more plain land compare to others.

Table 2. Information on household reporting income from different sources of livelihood

\begin{tabular}{|c|c|c|c|c|c|}
\hline Description & \multicolumn{5}{|c|}{ Name of Union Council } \\
\hline Farm livelihood sources & Lilownai & Kuz kana & Shahpur & Pirkhana & Total \\
\hline Crop & $83(78.3)$ & $34(75.6)$ & $69(85.2)$ & $76(83.5)$ & $262(81.1)$ \\
\hline Livestock & $57(53.8)$ & $16(35.6)$ & $27(33.3)$ & $37(40.7)$ & $137(42.4)$ \\
\hline Forest & $68(64.2)$ & $27(60.0)$ & $52(64.2)$ & $54(59.3)$ & $201(62.2)$ \\
\hline Land rented out & $24(22.6)$ & $15(33.3)$ & $23(28.4)$ & $16(17.6)$ & $78(24.1)$ \\
\hline Agric. Wages & $36(34.0)$ & $15(33.3)$ & $2(2.5)$ & $13(14.3)$ & $66(20.4)$ \\
\hline Farm machinery & $10(9.45)$ & $8(17.8)$ & $6(7.4)$ & $8(8.8)$ & $31(9.91)$ \\
\hline Fruit & $47(44.3)$ & $17(37.8)$ & $30(37.0)$ & $31(34.1)$ & $125(38.7)$ \\
\hline Vegetables & $10(4.7)$ & $3(6.7)$ & $0(0.0)$ & $3(3.3)$ & $11(3.4)$ \\
\hline Fodder & $27(25.5)$ & $13(28.9)$ & $10(12.3)$ & $16(17.6)$ & $64(19.8)$ \\
\hline \multicolumn{6}{|l|}{ Non-farm livelihood sources } \\
\hline Small scale business & $29(27.4)$ & $20(44.4)$ & $38(46.9)$ & $35(38.5)$ & $122(37.8)$ \\
\hline Public and private services & $57(53.8)$ & $21(46.7)$ & $35(43.2)$ & $44(48.4)$ & $157(48.6)$ \\
\hline Foreign Remittance & $11(10.4)$ & $11(24.4)$ & $13(16.0)$ & $14(15.4)$ & $49(15.2)$ \\
\hline Home Remittance & $52(49.1)$ & $23(51.1)$ & $32(39.5)$ & $42(46.2)$ & $149(46.1)$ \\
\hline Wage & $32(30.2)$ & $24(53.3)$ & $29(35.8)$ & $37(40.7)$ & $122(37.8)$ \\
\hline Pension & $3(2.8)$ & $2(4.4)$ & $1(1.2)$ & $3(3.3)$ & $9(2.8)$ \\
\hline Other* & $92(86.8)$ & $23(51.1)$ & $26(32.1)$ & $49(53.8)$ & $190(58.8)$ \\
\hline
\end{tabular}

Source: Field data, 2016,

Note: Figures in parenthesis is the percentages

*This include income includes income from affiliation with political organization, bank saving and any productive organization membership etc. 
The farm livelihood sources of income were comprised of different crops including vegetables, livestock, forests, and orchards, rented out the land, farm wages, and farm machinery. The lion share of contribution towards household's income from farm livelihood sources was the income from crops. The average annual income per household from crops was Rs. 65340 , followed by income from forests and livestock respectively. The remaining farm sources of livelihood mentioned above were contributing very less to the total household income. The detail can be seen from the Table 3 .

\subsection{Income from Non-farm Livelihood Sources}

Farm income sources were not providing enough income to run the household business. The majority of the households had allocated their family labor into different non-farm economic activities for earning income. These include income from small scale businesses, public/private sector services, both home and foreign remittances, daily wage, pension and income from other sources available to them. The data in this regard is presented in Table 3. The findings show that public/private sector employment was the major source of non-farm source of livelihood for the rural households in the research area. About 38 percent of the non-farm income was from the services sector. Some of the households' members were migrated in search of better employment to other parts of the country or abroad and they were sending remittances to back home. This source of livelihood was equally popular among the rural households in the non-farm income sources. They were sending (both home as well as foreign) which were contributing $23.60 \%$ to the total income of the households. These were followed by small scale businesses that were contributing $20.42 \%$ of the income to the total income from non-farm sources.

\subsection{Average Annual Income of the Reporting Household from Different Sources of Livelihood}

The above analysis regarding income of households from different sources was based on the data of the total sample households. In this section, the analysis is based on those households only that had actually accrued income from different livelihood sources. Data in Table 4 depict the average household income from farm and on-farm sources of livelihood in sample union councils in the area. By looking into the figures the households in the union council Lilownai had the highest average income while union council Shahpur the lowest income from farm sources. However, the annual average income from farm sources was higher in Shahpur and lower in Kuzkana. While comparing the income from non-farm sources it was found that in union council Lilownai and Shahpur had the highest average annual income while the union council Kuzkana and Pirkhana had the lowest income in this regard. Detail can be seen from the Table 3. The reason is the presences of multiple livelihood sources in these union councils. While in Kuzkana and Pirkhana the average income from and nonfarm sources was low, because of single or two sources of livelihood.

Table 3. Annual average income per household from different sources based on all household (Amount in Rs)

\begin{tabular}{|c|c|c|c|c|c|}
\hline Livelihood Sources & Lilownai & Kuz kana & Shahpur & Pirkhana & Total \\
\hline Total $(A+B)$ & 479312 & 411004 & 375568 & 442436 & 433390 \\
\hline A. Farm sources of livelihood & 140870 & 110348 & 133667 & 133072 & 132617 \\
\hline Crop & 59924 & 47404 & 81235 & 66371 & 65340 \\
\hline Livestock & 29000 & 5822 & 8000 & 18167 & 17453 \\
\hline Forest & 21637 & 12022 & 21741 & 21527 & 20293 \\
\hline Land rented out & 11368 & 12622 & 6543 & 7033 & 9111 \\
\hline Agriculture wages & 5840 & 7778 & 247 & 2604 & 3796 \\
\hline Farm machinery & 3226 & 16222 & 9383 & 10000 & 8489 \\
\hline Fruit & 6370 & 5489 & 5259 & 4568 & 5461 \\
\hline Vegetables & 1302 & 400 & - & 1077 & 786 \\
\hline Fodder & 2203 & 2589 & 1259 & 1725 & 1885 \\
\hline B. Non-farm sources of livelihood & 338443 & 300656 & 241901 & 309362 & 300775 \\
\hline Small scale business & 55849 & 59244 & 64444 & 66264 & 61412 \\
\hline Public and private services & 138132 & 87178 & 89728 & 119648 & 113687 \\
\hline Foreign Remittance & 25094 & 47333 & 29827 & 25714 & 29554 \\
\hline Home Remittance & 48425 & 54556 & 29840 & 37022 & 41406 \\
\hline Wage & 8160 & 23889 & 10296 & 10538 & 11557 \\
\hline Pension & 2264 & 3556 & 951 & 4319 & 2693 \\
\hline Other & 60519 & 24900 & 16815 & 45857 & 40466 \\
\hline Number of $\mathbf{H H}$ & 106 & 45 & 81 & 91 & 323 \\
\hline
\end{tabular}

Source: Field data. 
Table 4. Average annual income of the reported households from livelihood sources (Rs)

\begin{tabular}{|c|c|c|c|c|c|}
\hline Livelihood sources & Lilownai & Kuz kana & Shahpur & Pirkhana & Total \\
\hline Total & 479312 & 411004 & 375568 & 442436 & 433390 \\
\hline \multicolumn{6}{|l|}{ Farm livelihood sources } \\
\hline Crop & 76529 & 62741 & 95362 & 79471 & 80553 \\
\hline Livestock & 53930 & 16375 & 24000 & 44681 & 41147 \\
\hline Forest & 33728 & 20037 & 33865 & 36278 & 32609 \\
\hline Land rented out & 50208 & 37867 & 23043 & 40000 & 37731 \\
\hline Agriculture Wages & 17194 & 23333 & 10000 & 18231 & 18576 \\
\hline Farm machinery & 68400 & 91250 & 126667 & 113750 & 101556 \\
\hline Fruit & 14366 & 14529 & 14200 & 13410 & 14111 \\
\hline Vegetables & 27600 & 6000 & 0 & 32667 & 23091 \\
\hline Fodder & 8648 & 8962 & 10200 & 9813 & 9227 \\
\hline \multicolumn{6}{|l|}{ Non-farm livelihood sources } \\
\hline Small scale business & 204138 & 133300 & 137368 & 172286 & 162590 \\
\hline Public and private services & 256877 & 186810 & 207657 & 247455 & 233892 \\
\hline Foreign Remittance & 266000 & 193636 & 185846 & 167143 & 198875 \\
\hline Home Remittance & 98712 & 106739 & 73242 & 82171 & 89758 \\
\hline Wage & 26212 & 44792 & 28759 & 26639 & 30598 \\
\hline Pension & 120000 & 80000 & 77000 & 131000 & 108750 \\
\hline Others & 69728 & 48717 & 52385 & 85163 & 68792 \\
\hline
\end{tabular}

Source: Field data, 2016.

\section{Conclusion and Recommendations}

It is concluded from the main findings of the study that livelihood sources of the household in the area are divided into two categories i.e. farm sources and non-farm sources. Farm sources of livelihood are generally dominate in rural areas and include crop, livestock, forest, rented out the land, agriculture wages labor, farm machinery, fruit, vegetable, and fodder. While the non-farm sources of livelihood includes small scale business, public and private services, foreign and domestic remittances, wages, pension and others sources. Agriculture wages income was mentioned by $20.7 \%$ household. In non-farm income, $39.3 \%$ respondents getting income from small scale businesses followed by $47.7 \%$ of the household pointed for the public and private services. On the average the sample households were earning Rs. 433,390 annually from these sources. Slight variations were found while comparing the income of sample union councils. The average annual income per household from crops was Rs. 65340 , followed by income from forests and livestock respectively. The majority of the households had allocated their family labor into different non-farm economic activities for earning income. Public/private sector employment was the major source of non-farm source of livelihood for the rural households in the research area. The study as a whole concludes that the farm sources of income contribute more to the livelihood of the rural people than the nonfarm sources of income. On the bases of study findings, the following recommendations are made. A number of livelihood sources were reported by the households and according the Human Development Report (2016), the area having the area having highest ranking in poverty among all the districts of Khyber Pakhtunkhwa. So in this situation these livelihood sources play a significant role in the alleviation of poverty. This is mainly because of the traditional farm practices in the study area. So there is a need to develop the agriculture through latest available technology with the conservation of the natural resources along with the financial support to dwellers of the area for sustainable reduction of poverty and development of the area to achieve the goals of Sustainable Development (2016) of eradicating poverty in all areas of the of the world.

\section{References}

[1] Abid, M., Schneider, U. A., and Scheffran, J. (2016). Adaptation to climate change and its impacts on food productivity and crop income: Perspectives of farmers in rural Pakistan. Journal of Rural Studies, 47, 254-266.

[2] Adams, W. M., and Mortimore, M. J. (1997). Agricultural intensification and flexibility in the Nigerian Sahel. Geographical Journal, $150-160$.

[3] Ahmed, N. (2009). The sustainable livelihoods approach to the development of fish farming in rural Bangladesh. Journal of international farm management, 4(4), 1-18.

[4] Ahmed, N., Wahab, M. A., and Thilsted, S. H. (2007). Integrated aquaculture-agriculture systems in Bangladesh: potential for 
sustainable livelihoods and nutritional security of the rural poor Aquaculture Asia, 12(1), 14.

[5] Ahsan Ullah, A. K. M., and Routray, J. K. (2007). Rural poverty alleviation through NGO interventions in Bangladesh: how far is the achievement? International Journal of Social Economics, 34(4), 237-248

[6] Anseeuw, W., Laurent, C., Modiselle, S., Carsten, J., and van der Poll, S. (2001). Diversity of the rural farming households and policy issues: an analysis based on a case study in the Northern Cape Province in South Africa.

[7] Babulo, B., Muys, B., Nega, F., Tollens, E., Nyssen, J., Deckers, J., and Mathijs, E. (2008). Household livelihood strategies and forest dependence in the highlands of Tigray, Northern Ethiopia. Agricultural Systems, 98(2), 147-155.

[8] Bailey, C., and Jentoft, S. (1990). Hard choices in fisheries development. Marine policy, 14(4), 333-344.

[9] Barrett, C. B., Reardon, T., and Webb, P. (2001). Nonfarm income diversification and household livelihood strategies in rural Africa: concepts, dynamics, and policy implications, Food policy, 26(4), 315-331.

[10] Bhuiyan, A. B., Siwar, C., Islam, A., and Rashid, M. (2012). The approaches of Islamic and conventional microfinancing for poverty alleviation and sustainable livelihood. American Journal of Applied Sciences, 9(9), 1385-1389.

[11] Carley, M., and Christie, I., (2000). Managing sustainable development, Earthscan.

[12] Carr, E. R., (2013). Livelihoods as Intimate Government: Reframing the logic of livelihoods for development, Third world quarterly, 34(1), 77-108.

[13] Chambers, R., and Conway, G. (1992). Sustainable rural livelihoods: practical concepts for the 21st century. Institute of Development Studies (UK).

[14] Clot, N., and Carter, J., (2009). Disaster risk reduction: a gender and livelihood perspective. Info resources, Focus, 2(09).

[15] Cochran, W., ling Techniques, S., (1963). Chapter 5, Sampling Techniques.

[16] Dercon, S., and Krishnan, P. (1996). Income portfolios in rural Ethiopia and Tanzania: choices and constraints. The Journal of Development Studies, 32(6), 850-875.

[17] Diao, X., Dorosh, P., Rahman, S. M., (2007). Market opportunities for African agriculture: a general equilibrium examination of demand-side constraints on agricultural growth in East and Southern Africa.

[18] Ellis, F. (1998). Household strategies and rural livelihood diversification. The journal of development studies, 35(1), 1-38.

[19] Ellis, F. (2000). The determinants of rural livelihood diversification in developing countries. Journal of Agricultural Economics, 51(2), 289-302.

[20] FAO, F. (2011). Agricultural Organization of the United Nations (2004). FAO statistical yearbook 2005, 6 .

[21] Gautam, Y., Andersen, P. (2016). Rural livelihood diversification and household well-being: Insights from Humla, Nepal. Journal of Rural Studies, 44, 239-249.
[22] Jahan, S., Jespersen, E., Mukherjee, S., Kovacevic, M., Bonini, A., Calderon, C., Cazabat, C., Hsu, Y., Lengfelder, C., Lucic, S., (2016). Human development report 2016: Work for human development, UNDP: New York, NY, USA.

[23] Little, P. D., Smith, K., Cellarius, B. A., Coppock, D. L., and Barrett, C. (2001). Avoiding disaster: diversification and risk management among East African herders. Development and Change, 32(3), 401-433.

[24] Mayoux, L. (2000). Poverty elimination and the empowerment of women, London: Target Strategy.

[25] Olsson, L., Opondo, M., Tschakert P. (2014). Climate change 2014: livelihoods and poverty. Contribution of working group II to the fifth assessment report of the intergovernmental panel on climate change. Cambridge University Press, Cambridge

[26] O'Laughlin, B. (2004). Rural livelihood and diversity in developing countries. Book reviews. Development and Change, 35(2), 385-403.

[27] Perret, S. (2003). Insights into poverty and the diversity of livelihood systems in wool production communities of the Easter Cape Province in By Marijke, D. H., and Nick, V., eds., Local insitutional innovation and pro-poor agricultural growth: The case of small-woolgrowers associations in South Africa, Garant, Belgique: Antwerp, 117-139.

[28] Reardon, T., Berdegué, J., and Escobar, G. (2001). Rural nonfarm employment and incomes in Latin America: overview and policy implications. World development, 29(3), 395-409.

[29] Reed, M., Podesta, G., Fazey, I., Geeson, N., Hessel, R., Hubacek, K., Letson, D., Nainggolan, D., Prell, C., and Rickenbach, M. (2013). Combining analytical frameworks to assess livelihood vulnerability to climate change and analyse adaptation options, Ecological Economics, 94, 66-77.

[30] Schwarze, S., Schippers, B., Weber, R., Faust, H., Wardhono, A Zeller, M., Kreisel, W. (2007). Forest products and household incomes: evidence from rural households living in the rainforest margins of Central Sulawesi, In Stability of Tropical Rainforest Margins (pp. 207-222). Springer Berlin Heidelberg.

[31] Scoones, I. (2009). Livelihoods perspectives and rural development. The Journal of Peasant Studies, 36(1), 171-196.

[32] Stull, V., Bell, M. M., Ncwadi, M. (2016). Environmenta apartheid: Eco-health and rural marginalization in South Africa Journal of Rural Studies, 47, 369-380.

[33] Szirmai, A. (2005). The dynamics of socio-economic development: an introduction, Cambridge University Press.

[34] Unni, J. (1996). Diversification of economic activities and nonagricultural employment in rural Gujarat. Economic and Political Weekly, 2243-2251.

[35] World Bank. (2008). Gender in agriculture sourcebook Agriculture and Rural Development. Washington, DC: World Bank Group.

http://documents.worldbank.org/curated/en/171561468316139195 /Gender-in-agriculture-sourcebook. 